\title{
Correlation between the quality indicators of activated coal in vodka technology
}

\author{
Tatiana Shendrik ${ }^{1}$, Leonid Levandovskyi ${ }^{2}$, \\ Anatolii Kuts $^{3}$, Vitalii Prybylskyi ${ }^{3}$, Margarita Karputina ${ }^{3}$
}

\author{
1 - L.M. Litvinenko Institute of Physical-Organic Chemistry and Coal Chemistry of the \\ National Academy of Sciences of Ukraine, Kyiv, Ukraine \\ 2 - Kyiv National University of Trade and Economics, Kyiv, Ukraine \\ 3 - National University of Food Technologies, Kyiv, Ukraine
}

\section{Keywords:}

Active coal

Sorption

Alcohol

Vodka

Correlations

\section{Article history:}

Received

16.11.2018

Received in

revised form

30.04.2019

Accepted

29.05.2019

\section{Corresponding author:}

Tatiana Shendrik

E-mail:

shendriktg@

gmail.com

DOI:

10.24263/2310-

1008-2019-7-1-6

\section{Abstract}

Introduction. The purpose of the publication is to establish correlation relations between the quality indicators of active coal (AC) used in the distillery production in vodka technology.

Materials and methods. AC of natural origin, which is used for distillery production. Standard methods of determination and quantitative characteristics of AC quality indicators. Mathematical-statistical methods of research are linear correlation analysis based on the Pearson correlation coefficient.

Results and discussion. It was found that the correlation coefficient $(r)$ between iodine adsorption activity $\left(A_{i .}\right)$, which characterizes the amount and volume of micropore AC with diameter $D_{m}<2 \mathrm{~nm}$, including nanopor with diameter $D_{m}<1 \mathrm{~nm}$, and methylene blue $\left(A_{m . b .}\right)$, which depends on the mesopore volume with a diameter $D_{m e}=2 \ldots .50 \mathrm{~nm}$, is equal to 0.93 . The total volume of the micro- and mesoporous space determines the total sorption capacity of $\mathrm{AC}$ relative to the organic impurities present in the water-alcohol mixtures. AC's sorption activity also depends on its fractional composition. The correlation (reverse dependence) between adsorption activity on acetic acid $\left(A_{\text {a.a. }}\right)$ and the mass fraction of the sorbent residue on a screen with a cloth №10 $\left(F_{\text {№10 }}\right)$ with a coefficient $r=-0,94$ was established. Reducing the mass fraction of the residual on a screen with a cloth from $97 . . .98 \%$ to $62 . .64 \%$ leads to an increase in adsorption activity of $\mathrm{AC}$ by acetic acid to $117 \mathrm{ml}$ versus $62 \mathrm{ml}$. This is directly due to the fact that the residual sorbent on the sieve № 10 has a large area of the surface of the microporous and mesoporous space due to the reduced size of the grains. The total volume of sorbents in water $\left(T_{p . v .}\right)$ is directly proportional to the mass fraction of water soluble ash $\left(M_{\text {w.a. }}\right) r=0.92$ and the mass fraction of moisture $\left(M_{m}\right)$ at $r=0.99$. In order to release $\mathrm{AC}$ from water soluble ashes and increase the volume of pore space, it will be logical to wash the prepared AC with water and then dry it to the water content in the coal to $2 \%$. It was established that the fractional composition, the mass of the residue on the sieve with canvas № $36\left(F_{N 036}\right)$ is directly dependent on the mass fraction of ash $\left(M_{a .}\right)(r=0.91)$ and the mass fraction of water soluble ash $\left(M_{\text {w.a. }}\right)(r=0.91)$, which indirectly indicates the influence of inorganic components $\mathrm{AC}$ on its mechanical strength. It is assumed that in the largest fractions of $\mathrm{AC}$ with a mass of the residue on the sieve with canvas № $36\left(F_{\text {№3 }}=2.1 \%\right)$ contains more ash in the macropore space $\left(M_{a}=5.12 \%\right)$, including water soluble ash $\left(M_{w . a .}=1.95 \%\right)$.

Conclusions. As a result of the analysis of standard quality indicators $\mathrm{AB}$ and the study of their mutual dependencies using the mathematicalstatistical method using the Pearson correlation coefficients, it has been found that $92 \%$ (12 out of 13) indicators have strong internal relationships that are characterized by a "very high" correlation force with coefficients $\mathrm{r}=0.90-0.99$. 


\section{Introduction}

Today, one of the topical problems of alcoholic beverage production is the improvement of alcohol production technologies at the main stages of production, the development of technical means and the search for optimal conditions for technological processes for their implementation. The purpose of the publication is to establish correlation relations between the quality indicators of active coal used in the distillery production in vodka technology.

\section{Analysis of recent researchs and publications}

The most important stages in the production of vodka (Oliinyk et al, 2016, 2014; Kuzmin et al, 2014, 2015, 2017) [1-7] are the creation of water-alcohol mixtures (Kuzmin et al, 2013, 2014, 2017, 2018) [8-14] and processing them with activated carbon (Oliinyk et al, 2014; Mukhin et al, 2003, 2004) $[2,15,16]$. The quality of the activated carbon depends on the quality of the finished product (Mukhin et al, 2003, 2004; Petrov et al, 2004, 2005) [15-18]. Often, the main raw material for activated carbon is a wide range of precursors (natural coal, wood, carbonaceous wastes of various origin, etc.) (Marsh, Rodriguez-Reinoso, 2006; RiveraUtrilla et al, 2011; Bansal, Goyal, 2005) [19-21].

There are several methods for producing activated coal, the most common of which is the activation of gases and water vapor at temperatures of $800-900{ }^{\circ} \mathrm{C}$ (the so-called "physical" activation) (Marsh, Rodriguez-Reinoso, 2006; Kong et al, 2013; Matos et al, 2011) $[19,22,23]$ and thermochemical activation, involving reagents of various nature (Marsh, Rodriguez-Reinoso, 2006; Kong et al, 2013; Kuzmin et al, 2017; Kwiatkowski et al, 2017; Kumar, Jena, 2017; Zubkova, 2011) [19, 22, 24-28]. Advantages of chemical activation: onestage process; lower activation temperature; shorter activation time; large exits; more developed surface; more controlled microporosity (Lillo-Ródenas et al, 2007) [29]. However, chemical activation involves the use of an activating agent $\left(\mathrm{ZnCl}_{2}, \mathrm{H}_{3} \mathrm{PO}_{4}, \mathrm{NaOH}, \mathrm{KOH}\right.$, etc. $)$ (Kuzmin et al, 2017; Kwiatkowski et al, 2017; Kumar, Jena, 2017) [24-27], which is introduced by impregnation or stirring, after which the raw material is heated (activated) in an atmosphere of inert (or intrinsic) gases to a certain degree roasting (as a rule, up to 50$70 \%)$.

Activated charcoal is classified (Kinle, Bader, 1984; Roshchina, 1998) [30, 31]:

- for the predominant form of pores: spherical; slit-shaped (Figure 1); bottle-shaped;

- by pore size: macropores; mesopores; micropores (Figure 2);

- for porosity: large porosity; fine porosity; active coke; carbon molecular sieve (Table 1).

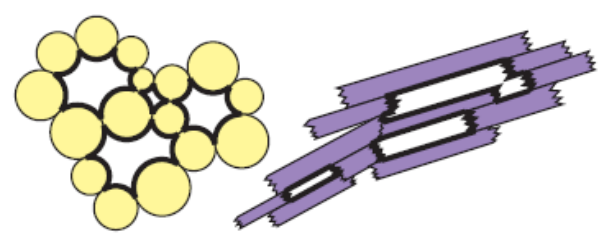

a

b

Figure 1. Characteristics of pores in the form:

a - spherical; b - slit-shaped 
Characteristics of activated carbon for porosity (Kinle, Bader, 1984) [30]

\begin{tabular}{|l|c|c|c|}
\hline The name of the coal & $\begin{array}{c}\text { Macropores } \\
\boldsymbol{D}_{\boldsymbol{m a}}>\mathbf{5 0} \mathbf{~ n m}\end{array}$ & $\begin{array}{c}\text { Mesopores } \\
\boldsymbol{D}_{\boldsymbol{m} \boldsymbol{e}}=\mathbf{2 . . . 5 0} \\
\mathbf{n m}\end{array}$ & $\begin{array}{c}\text { Micropores } \\
\boldsymbol{D}_{\boldsymbol{m}}<\mathbf{2} \mathbf{~ n m}\end{array}$ \\
\hline Volume of pores of broadly porous coal, $\mathrm{cm}^{3} / \mathrm{g}$ & 0,4 & $0,6 \ldots 0,8$ & $0,1 \ldots 0,2$ \\
\hline Volume of pores of finely porous coal, $\mathrm{cm}^{3} / \mathrm{g}$ & 0,3 & 0,1 & $0,6 \ldots 0,8$ \\
\hline Volume of active coke pore, $\mathrm{cm}^{3} / \mathrm{g}$ & 0,1 & 0,1 & 0,1 \\
\hline Volume of pore carbon molecular sieves, $\mathrm{cm}^{3} / \mathrm{g}$ & 0,1 & 0,05 & 0,25 \\
\hline
\end{tabular}

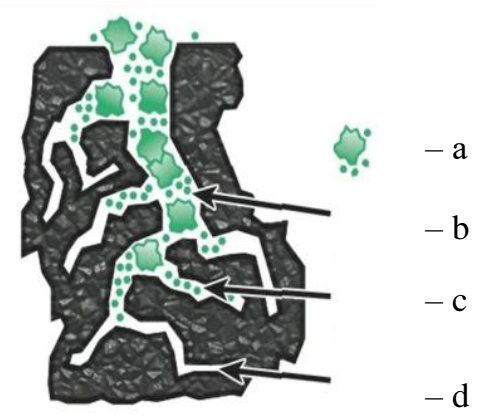

Figure 2. Matrix of pore space in activated charcoal:

a - adsorbed molecules in size of particles (large, small); b - macropores $D_{m a}>50 \mathrm{~nm} ; \mathrm{c}$ - mesopores $D_{m e}=2 \ldots 50 \mathrm{~nm} ; \mathrm{d}-$ micropores $D_{m}<2 \mathrm{~nm}$

Characteristics of macropores: diameter $D_{m a}>50 \mathrm{~nm}$; volume $V_{m a}=0,2 \ldots 0,8 \mathrm{~cm}^{3} / \mathrm{g}$; surface $S_{m a}=0,5 \ldots 2,0 \mathrm{~m}^{2} / \mathrm{g}$. Macropores are channels for penetration of substances deep into the sorbent, on the surface of which it is impossible to capillary condensation of steam (Kinle, Bader, 1984) [30].

Characteristic mesopores: $D_{m e}=2 \ldots 50 \mathrm{~nm} ; V_{m e}=0,02 \ldots 0,10 \mathrm{~cm}^{3} / \mathrm{g} ; S_{m e}=20 \ldots 70 \mathrm{~m}^{2} / \mathrm{g}$. Filling the mesoporous volume occurs when capillary condensation of steam, adsorption - at pressures, lower boundaries of capillary condensation (Kinle, Bader, 1984) [30].

Characteristics of the micropores: $D_{m i}<2 \mathrm{~nm} ; V_{m i}=0.20 \ldots 0.60 \mathrm{~cm}^{3} / \mathrm{g}$. Micropores represent the space in which the adsorption field appears at low partial pressure, even before capillary condensation (Kinle, Bader, 1984) [30].

For the solution of special problems of the liquor industry, the production of activated coal with certain properties is relevant. Thus, the adsorption activity of activated charcoal by acetic acid characterizes the catalytic characteristics of activated charcoal, with the decrease of activity, regeneration of active coal or replacement is recommended, with increase-an increase in the content of aldehydes in the water-alcohol mixture (Petrov et al, 2004) [17].

The adsorption activity of activated charcoal by iodine depends on the amount and volume of micropores and determines the sorption capacity of activated charcoal relative to the impurities of organic substances present in water-alcohol mixtures (Petrov, Limonov, 2005) [18].

The oxidation of water-alcohol mixtures by the Lang method is an indicator of the effectiveness of the action of activated charcoal, which is determined in water-alcohol mixtures before and after treatment with activated charcoal. The difference in oxidation for high-grade vodka should be $\geq 2.5$ minutes, for low-grade vodka -2 minutes. If the difference is less indicated - active coal is 


\section{— Food Technology}

regenerated or replaced (Petrov, Limonov, 2005; Lovyahin et al. 2008) [18, 32].

The hardness of active coal - characterizes the ability of active coal to withstand the pressure of the liquid and not crushed by rubbing the particles one by one (Mukhin et al, 2003, 2004; Petrov et al, 2004; Roshchina, 1998) [15-17, 31].

The fractional composition of activated carbon must also meet certain criteria. The high content of small particles of activated carbon leads to increased removal of activated carbon from coal columns, as well as to "loosening" the layer of activated carbon in a column, which leads to additional abrasion of activated carbon (Petrov et al, 2004) [17].

The mass fraction of active coal ash characterizes the amount of mineral impurities in activated charcoal. Low ash content and low content of water soluble ash reduce the ability of water-alcoholic raw materials to aldehyde formation (Mukhin et al, 2003, 2004; Petrov et al, 2004; Roshchina, 1998) $[15-17,31]$.

The cost of activated charcoal is also an important technical and economic factor, but it is not analyzed in this paper.

Traditionally, the BAU-A grade of activated charcoal, obtained by the method of physical activation with water vapor at $T \geq 800^{\circ} \mathrm{C}$, is used in the distillery production, which has the following characteristics: $\rho=200 \mathrm{~g} / \mathrm{dm}^{3}, V_{\Sigma}=1.50 \mathrm{~cm}^{3} / \mathrm{g} ; V_{m a}=1.19 \mathrm{~cm}^{3} / \mathrm{g} ; V_{m e}=0.08 \mathrm{~cm}^{3} / \mathrm{g} ; V_{m i}=0.23 \mathrm{~cm}^{3} / \mathrm{g}$; $S_{m e}=57 \mathrm{~m}^{2} / \mathrm{g}[17]$.

The main advantages of BAU-A type activated coal (Petrov et al, 2004) [17]: high specific surface area $\left(S=500 \ldots 800 \mathrm{~m}^{2} / \mathrm{g}\right)$, which provides good organoleptic characteristics of vodkas.

The main disadvantages of activated charcoal BAU-A brand (Mukhin et al, 2003, 2004) [15, 16]: high alkalinity of the surface $(\mathrm{pH} 9 \ldots 11)$; low mechanical hardness $(37 \ldots 42 \%)$; presence of water soluble ash $0,5 \ldots 0,7 \%$; uneven fractional composition, which leads to an independent sorting of activated charcoal in the adsorber, with large-sized fractions located in the middle of the column, smaller - in the periphery, which changes the velocity of the water-alcohol mixture in the adsorber.

The spent activated charcoal BAU-A grades are regenerated at a temperature of $700-900^{\circ} \mathrm{C}$ by pyrolysis and activated at a temperature of $110 \ldots 115^{\circ} \mathrm{C}$ with water vapor (Mukhin et al, 2003, 2004) $[15,16]$.

Based on the critical analysis of literary sources, it is concluded that the active charcoal of BAUA brand does not fully meet the requirements of alcoholic beverage production, which is why the search for alternative active coal is needed and the development of additional requirements for activated carbon in terms of: hardness; adsorption activity (Shulman-Babkova's method); adsorption activity by acetic acid (Oshmyan method).

In the distillery production prospects are active charcoal from fruit stones, shells of coconut, walnuts, etc., which have: a higher bulk density; higher adsorption activity by acetic acid (UAK 130 units, BAU-A - 60 units); a significant difference in oxidation between vodka and aqueousalcoholic mixture (UAK - 3.8 minutes, BAU-A - 3.0 minutes); less amount of water soluble ash; greater intergenerational resource of activated carbon; higher hardness than activated charcoal of BAU-A mark (Mukhin et al, 2003, 2004; Petrov et al, 2004) [15-17].

One of the promising areas for the creation of new adsorbents is the production of activated charcoal with particles of colloidal-dispersed silver deposited on its surface. As a result of the electrochemical potential difference between silver and activated carbon there are positive changes in the surface of activated carbon: the intensification of oxidation-reduction reactions and reactions of esterification; increase of hardness of activated carbon; increase of the active coal activity resource; reduction of the aldehyde formation process; increase of organoleptic parameters of vodkas (Tarasov et al, 2003) [33].

The main disadvantages of activated carbon impregnated with silver are: the reduction of the efficiency of treatment of water-alcohol mixtures as a result of the gradual washing out of the surface of activated carbon silver (Tarasov et al, 2003; Zhabkina et al, 2005) [33, 34]. 


\section{Materials and methods}

Materials. The object of the study was active carbons of various types: crushed activated wood charcoal BAU-A; charcoal activated wood crushed BAU-A-LVZ; BAU-A silver impregnated active carbon BAU-A-Ag; active stone coal MeKS; coconut activated carbon KAU-2; anthracite active coal KDS-A (Table 2).

Table 2

Characteristics of active carbons

\begin{tabular}{|c|c|c|c|c|c|c|c|}
\hline \multirow[b]{2}{*}{ Symbol } & \multirow[b]{2}{*}{ Name of the indicator } & \multicolumn{6}{|c|}{ Brand of active coal } \\
\hline & & BAU-A & $\begin{array}{l}\text { BAU-A- } \\
\text { LVZ }\end{array}$ & $\begin{array}{c}\text { BAU-A- } \\
\text { Ag }\end{array}$ & MeKS & KAU-2 & KDS-A \\
\hline$A_{i .}$ & $\begin{array}{l}\text { Adsorption activity by } \\
\text { iodine, } \%\end{array}$ & 62 & 69 & 73 & 94 & 82 & 51 \\
\hline$A_{a . a}$ & $\begin{array}{l}\text { Adsorption activity by } \\
\text { acetic acid, ml }\end{array}$ & 64 & 73 & 82 & 117 & 67 & 62 \\
\hline$A_{m . b .}$ & $\begin{array}{l}\text { Adsorption activity by } \\
\text { methylene blue, } \mathrm{mg} / \mathrm{g}\end{array}$ & 129 & 141 & 169 & 273 & 265 & 117 \\
\hline$T_{p . v .}$ & $\begin{array}{l}\text { Total pore volume of } \\
\text { water, } \mathrm{cm}^{3} / \mathrm{g}\end{array}$ & 1,72 & 1,91 & 2,00 & 1,57 & 1,23 & 1,43 \\
\hline$B_{d}$ & Bulk density, g/dm ${ }^{3}$ & 215 & 221 & 228 & 572 & 524 & 691 \\
\hline$F_{\text {№36 }}$ & $\begin{array}{l}\text { Fractional composition, } \\
\text { mass of the residue on the } \\
\text { sieve with canvas: № } 36, \% \\
\end{array}$ & 1,6 & 1,4 & 2,1 & 0,1 & 0,2 & 0,1 \\
\hline$F_{\text {№10 }}$ & $\begin{array}{l}\text { Fractional composition, } \\
\text { mass of the residue on the } \\
\text { sieve with canvas: № } 10, \%\end{array}$ & 98,0 & 97,6 & 96,6 & 90,4 & 96,3 & 97,2 \\
\hline$F_{p}$ & $\begin{array}{l}\text { Fractional composition, the } \\
\text { mass of the residue on the } \\
\text { sieve with canvas: on the } \\
\text { pallet, } \%\end{array}$ & 0,4 & 1 & 1,3 & 9,5 & 3,5 & 2,7 \\
\hline$M_{a .}$ & Mass part of ash, $\%$ & 4,70 & 4,95 & 5,12 & 3,61 & 3,26 & 2,40 \\
\hline$M_{w . a .}$ & $\begin{array}{l}\text { Mass part of water-soluble } \\
\text { ash, } \%\end{array}$ & 1,64 & 1,87 & 1,95 & 1,27 & 1,04 & 0,78 \\
\hline$M_{i .}$ & Mass part of iron, $\%$ & 0,12 & 0,13 & 0,15 & 0,19 & 0,13 & 0,10 \\
\hline$M_{m}$ & Mass part of moisture, $\%$ & 3,8 & 4,1 & 4,5 & 3,2 & 2,1 & 2,9 \\
\hline$A_{r}$ & Abrasion resistance, $\%$ & 52,8 & 59,6 & 63,1 & 90,1 & 86,7 & 79,3 \\
\hline
\end{tabular}

The research methods are based on the research methods of active carbons by physicochemical parameters: adsorption activity by iodine; adsorption activity by acetic acid; adsorption activity by methylene blue; total pore volume of water; bulk density; fractional composition; mass part of ash; mass part of water-soluble ash; mass part of iron; mass part of moisture; abrasion resistance.

Linear correlation (Pearson). Pearson correlation coefficient measures the strength of the linear association between variables. Each variable should be continuous, random sample and approximately normally distributed (Hinkle et al, 2003) [35].

The correlation coefficient can take a range of values from +1 to -1 . Positive correlation 
coefficient means that if one variable gets bigger, the other variable also gets bigger, so they tend to move in the same direction. Negative correlation coefficient means that the variables tend to move in the opposite directions: If one variable increases, the other variable decreases, and vice-versa. When correlation coefficient is close to zero two variables have no linear relationship (Hinkle et al, 2003) [35].

There are many rules of thumb on how to interpret a correlation coefficient, but all of them are domain specific. For example, here is correlation coefficient (Table 3) interpretation for behavioral sciences offered by Hinkle et al, 2003 [35].

\section{Correlation coefficient interpretation by Hinkle et al, 2003 [35]}

Table 3

\begin{tabular}{|c|c|}
\hline Absolute value of coefficient $(\boldsymbol{r})$ & Strength of correlation \\
\hline $0,90 \ldots 1,00$ & Very high \\
\hline $0,70 \ldots 0,90$ & High \\
\hline $0,50 \ldots 0,70$ & Moderate \\
\hline $0,30 \ldots 0,50$ & Low \\
\hline $0,00 \ldots 0,30$ & Little, if any \\
\hline
\end{tabular}

\section{Results and discussions}

Table 4 presents the correlation matrix for the coals studied.

Marked correlations $(r)$ are significant at $p<0,05 ; N=6$

Table 4

\begin{tabular}{|c|c|c|c|c|c|c|c|c|c|c|c|c|c|}
\hline & $\boldsymbol{A}_{i}$ & & n.b. & $T_{p . v .}$ & $\boldsymbol{B}_{d .}$ & No36 & $F_{\text {№10 }}$ & $F_{p}$ & $M_{a}$ & $I_{\text {w.a. }}$ & $M_{i .}$ & $M_{m}$ & $A_{r}$ \\
\hline$\overline{A_{i .}}$ & & & & & & & & & & & 0,90 & & \\
\hline & & & & & & & & & & & & & \\
\hline & & & & & & & 8 & 7 & 27 & & & & 7 \\
\hline$T$ & & & & & & 77 & 20 & 40 & 87 & 92 & 19 & 99 & 0,7 \\
\hline$B_{d}$ & & & & & & & & & & & & & \\
\hline & & & 40 & & 0 & 1,00 & 0,50 & $-0,68$ & 0,91 & 0,91 & $-0,06$ & 0,88 & 0,8 \\
\hline & & & & & & & 1,00 & $-0,97$ & 4 & & 88 & 22 & $\overline{0,6}$ \\
\hline$\Gamma$ & & & & & & & 7 & & & & & & \\
\hline & & & & & & & 4 & $-0,44$ & 0 & & & 34 & 0,7 \\
\hline$\pi$ & & & & & & 0,91 & 2 & $-0,42$ & 9 & 1,00 & 25 & ,89 & 0,7 \\
\hline & & & & & & & $-0,88$ & & 24 & 0,25 & 00 & 0,15 & $0, \mathrm{~J}$ \\
\hline$v_{m}$ & & & & & & & & $-0,42$ & , ד, ד, & & & & 0,7 \\
\hline 4 & 52 & 45 & 0,75 &, 75 & 0,87 & 0,89 & $-0,69$ & 0,82 & $-0,77$ & $-0,75$ & 0,37 & 0,77 & 0 \\
\hline
\end{tabular}


The volume of iodine adsorbed by coal $\left(A_{i .}\right)$ is in the range of $51-94 \%$. Iodine adsorption activity (Figure 3 ) is directly related to the adsorption activity of the sorbent for methylene blue $\left(A_{m . b .}\right)$. Methylene blue adsorption activity is in the range of $117-273 \mathrm{mg} / \mathrm{g}$. The coefficient of pair correlation $(r)$ between the indices of the adsorption activity on iodine and methylene blue was $r=0.93$, which is characterized by "very high" correlation strength, since the value is in the range of $0.90-1.00$. The adsorption activity of active carbon in iodine depends on the number and volume of micropores, which are characterized by a diameter of $D_{m i}<2 \mathrm{~nm}$, including nanopores with a diameter of $D_{n}<1 \mathrm{~nm}$. The adsorption activity of the sorbent for methylene blue depends on the number and volume of mesopores, which are characterized by a diameter of $D_{m e}=2-50 \mathrm{~nm}$. The internal correlation between the adsorption activity of active carbon in iodine and methylene blue determines their total effect of the micropore and mesoporous space on the adsorption process. It determines the sorption capacity of activated carbon relative to the impurities of organic substances present in wateralcohol mixtures.

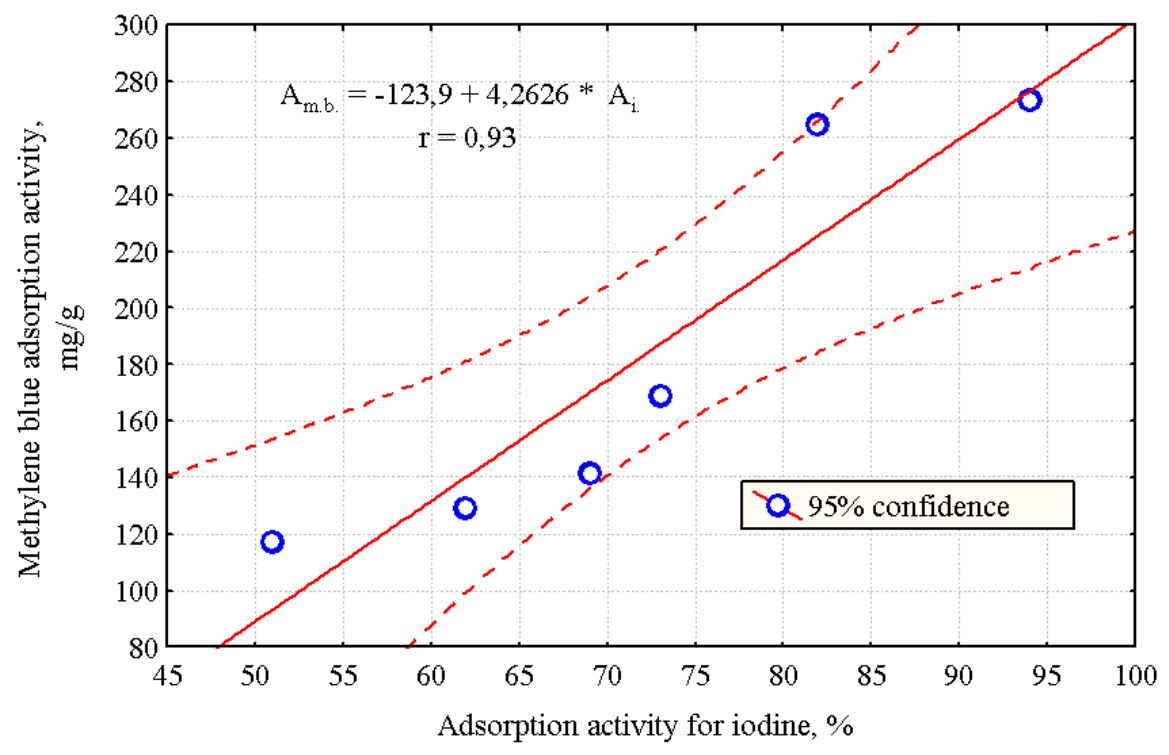

Figure 3. Dependence of adsorption activity for iodine on methylene blue adsorption activity

From the data of table 2 it can be seen that the active carbon of MeKS brand, which has the highest values of adsorption activity for iodine $-94 \%$ and adsorption activity for methylene blue $-273 \mathrm{mg} / \mathrm{g}$, has the most developed micropore and mesoporous space. The least developed total pore space is inherent in the structure of active carbon KDS-A, made of fossil coal - anthracite. It is characterized by the lowest values of adsorption activity for iodine $-51 \%$ and adsorption activity for methylene blue $-117 \mathrm{mg} / \mathrm{g}$. Interrelation of $A_{m . b}$. and $A_{i}$. shown in Figure 3. These qualities of sorbents are characterized by a "very high" correlation force $(r=0.93)$.

The sorption properties of porous materials are inextricably linked with their fractional composition. This relationship was considered by us on the example of the adsorption activity of the samples with respect to acetic acid $\left(A_{\text {a.a. }}\right)$ and the fractional composition of activated carbons. So, $A_{a . a .}$ the studied sorbents lie in the range of $62-117 \mathrm{ml}$. The coefficient of pair correlation $(r)$ between 
the indicators of the adsorption activity of acetic acid $\left(A_{\text {a.a. }}\right)$ and the fractional composition of activated carbon, characterized by weight $(\%)$ of the residue on the sieve with cloth № $10\left(F_{\text {№lol }}\right)$, was $\mathrm{r}=-0,94$ (Figure 4). This is characterized by a "very high" force of inverse (negative) correlation.

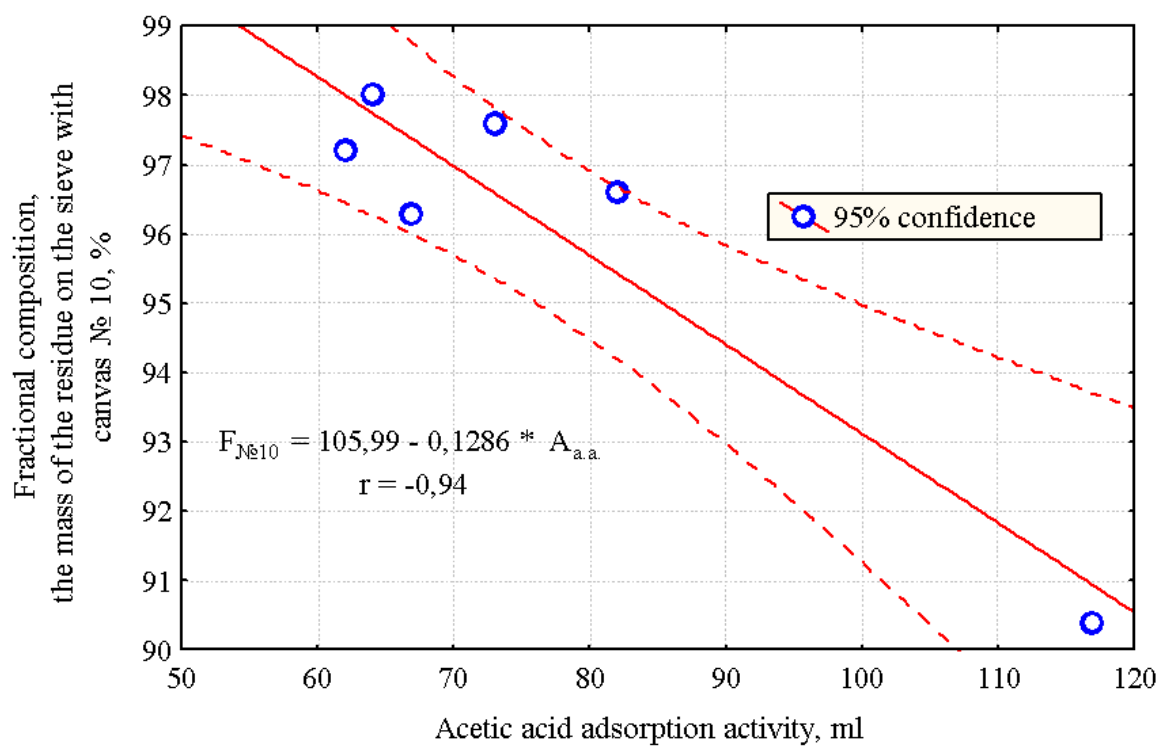

Figure 4. Dependence of acetic acid adsorption activity for fractional composition, the mass of the residue on the sieve with canvas№ 10

Interpretation of the results. A decrease in the fraction of active carbon fractions on a sieve with canvas № 10 from $98.0 \%$ to $90.4 \%$ leads to an increase in the adsorption activity of active carbon on acetic acid from 62 to $117 \mathrm{ml}$. This characterizes the presence of a smaller amount of the fine fraction on the sieve with the canvas number 10 , which has a greater surface area due to the developed micropore and mesoporous space, and, accordingly, increased adsorption activity on acetic acid.

It is known that the presence of iron in active carbon determines the catalytic properties of active carbon. At the same time, the mass fraction of iron $\left(M_{i}\right)$ also affects for the adsorption activity of active carbon for acetic acid $\left(A_{\text {a.a. }}\right)$. The coefficient of pair correlation $(r)$ between the indicators for adsorption activity for acetic acid $\left(A_{\text {a.a. }}\right)$ and the mass fraction of iron $\left(M_{i}\right.$.) was $r=0.96$ (Figure 5). This indicates a "very high" strength of direct (positive) correlation. An increase in the mass of iron in active carbon from $0.10 \%$ to $0.19 \%$ leads to an increase in the adsorption activity of active carbon on acetic acid from $62 \mathrm{ml}$ to $117 \mathrm{ml}$. At the same time, a decrease in the mass of iron in active carbon to $0.10 \%$ reduces the adsorption activity of active carbon on acetic acid to $62 \mathrm{ml}$.

The total pore volume of water $\left(T_{p . v .}\right)$ is in the range of $1.23-2.00 \mathrm{~cm}^{3} / \mathrm{g}$. This parameter (Figure 6-7) is in direct relationship with the mass portion of water soluble ash $\left(M_{\text {w.a. }}\right)$ and the mass portion of moisture $\left(M_{m}\right.$.). The coefficient of pair correlation $(r)$ between the indicators of the total pore volume of water and the mass fraction of water-soluble ash was $\mathrm{r}=0.92$. The relationship between the total pore volume of water and the mass fraction of moisture turned out to be even closer. The coefficient of pair correlation $(r)$ in this case was $r=0.99$, which means "very high" correlation force. Note that all three indicators are related to moisture, which is in the active carbon, and water absorbed in the process of determining 


\section{— Food Technology}

the total pore volume. That is, the larger the pore volume of water $\left(T_{p . v .}=2.00 \mathrm{~cm}^{3} / \mathrm{g}\right)$, determined by the standard method in active carbon, the more active carbon retains moisture $\left(M_{m .}=4.5 \%\right)$ and the more water-soluble ash is in the volume of active carbon $\left(M_{w . a .}=1.95 \%\right)$. Therefore, to release the sorbent from water-soluble ash and increase the pore volume, it is necessary to wash the activated carbon with water and then dry it to a mass of water of $2 \%$.

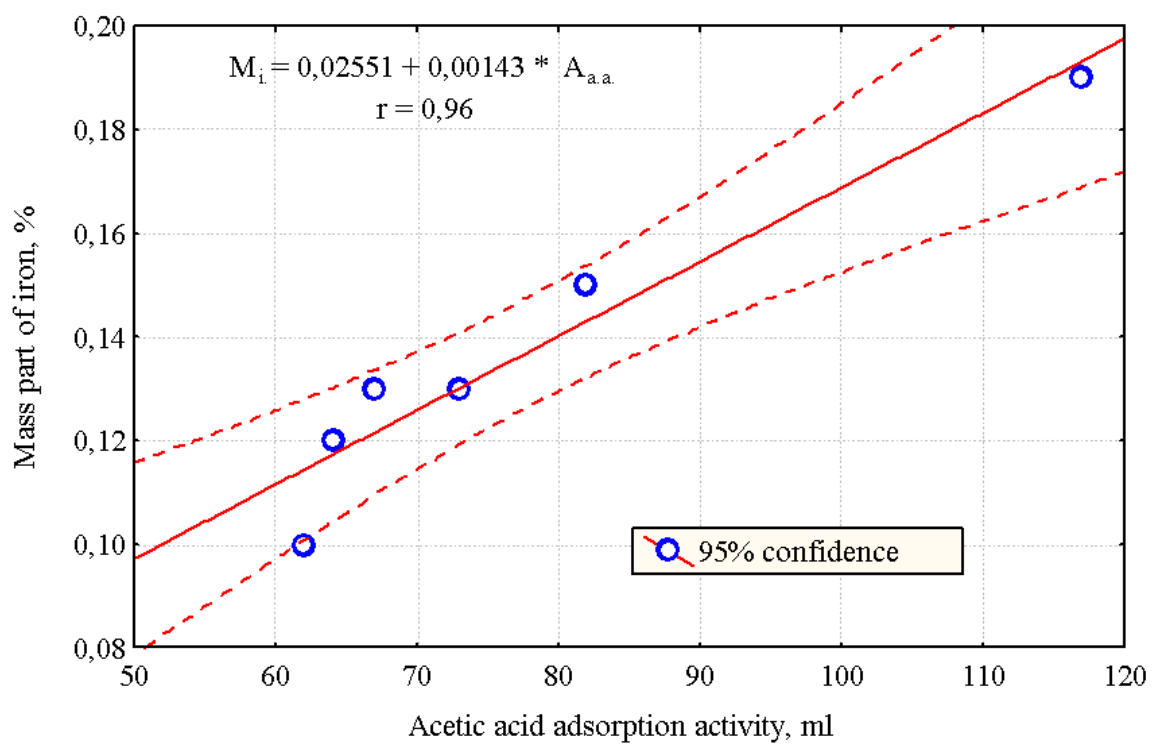

Figure 5. Dependence of acetic acid adsorption activity for mass part of iron

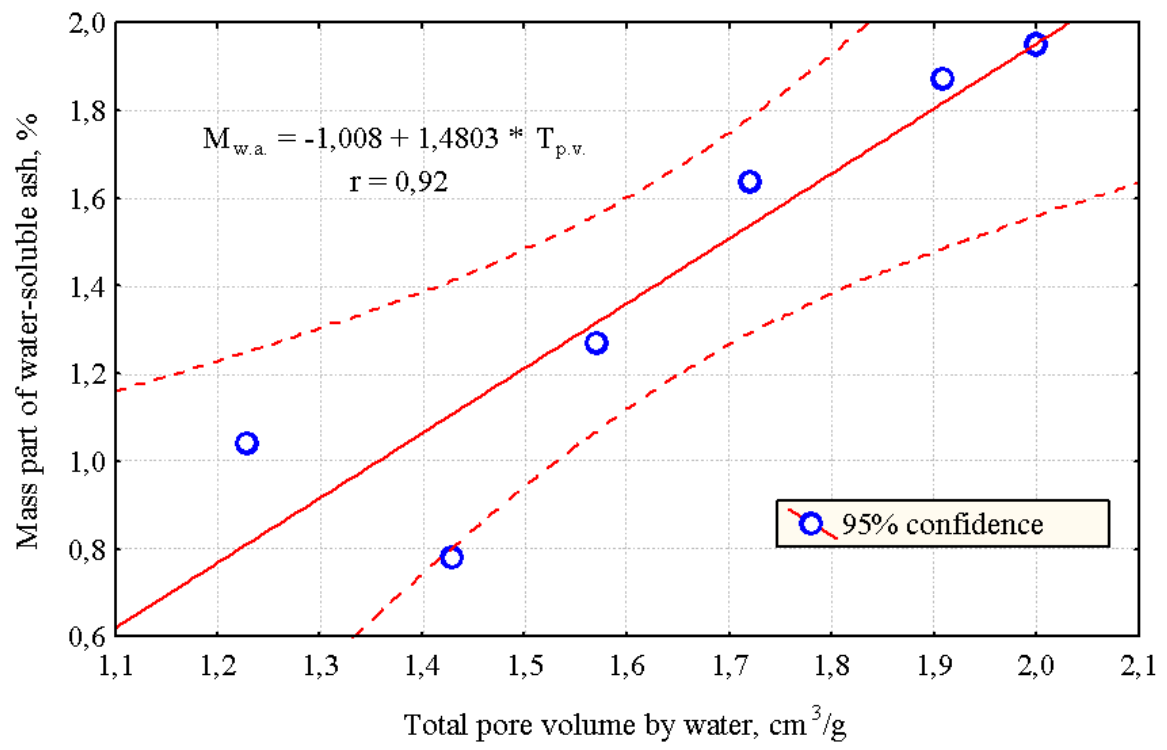

Figure 6. Dependence of total pore volume by water for mass part of water-soluble ash 


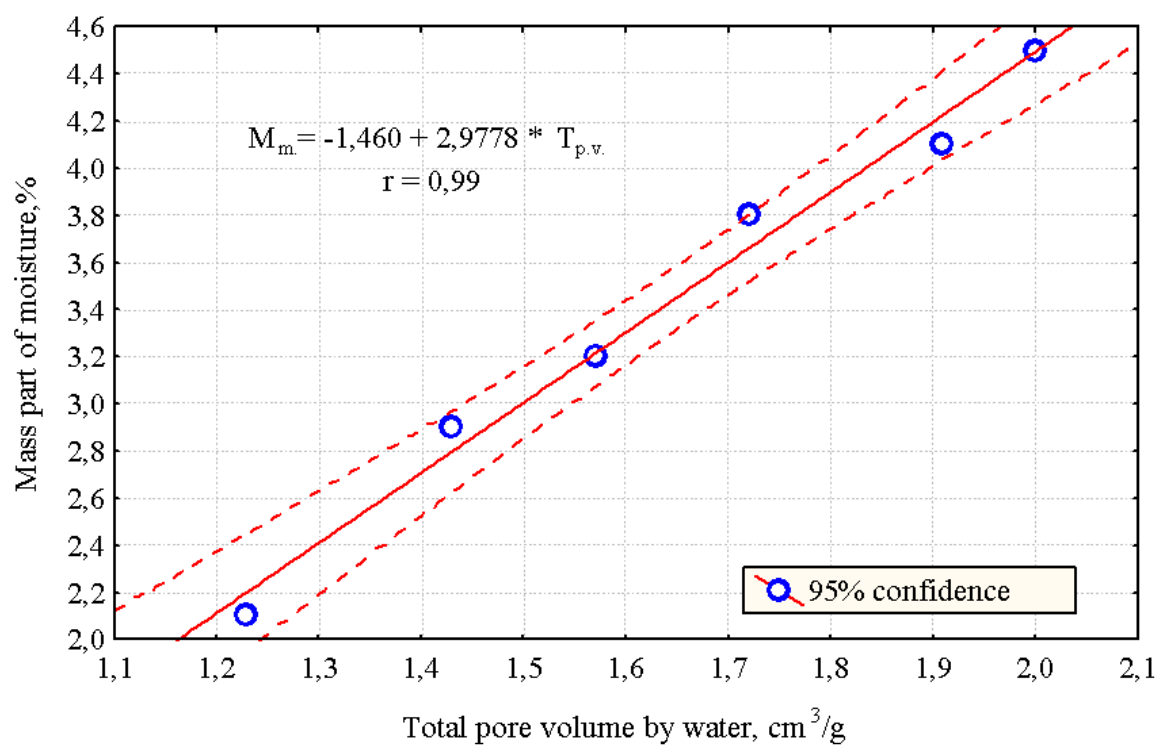

Figure 7. Dependence of total pore volume by water for mass part of moisture

One of the indicators characterizing the operational properties of active carbons is bulk density. The bulk density $\left(B_{d}\right.$. $)$ of the coals studied is in the range of $215-691 \mathrm{~g} / \mathrm{dm}^{3}$. At the same time, the bulk density $\left(B_{d .}\right.$ ) (Figure 8-10) is inversely related to the fractional composition of the sorbent, namely, to the mass portion of the residue on the sieve with web № $36\left(F_{\text {№36 }}\right)$, mass portion of ash $\left(M_{a .}\right)$, mass part of water soluble ash $\left(M_{\text {w.a. }}\right)$.

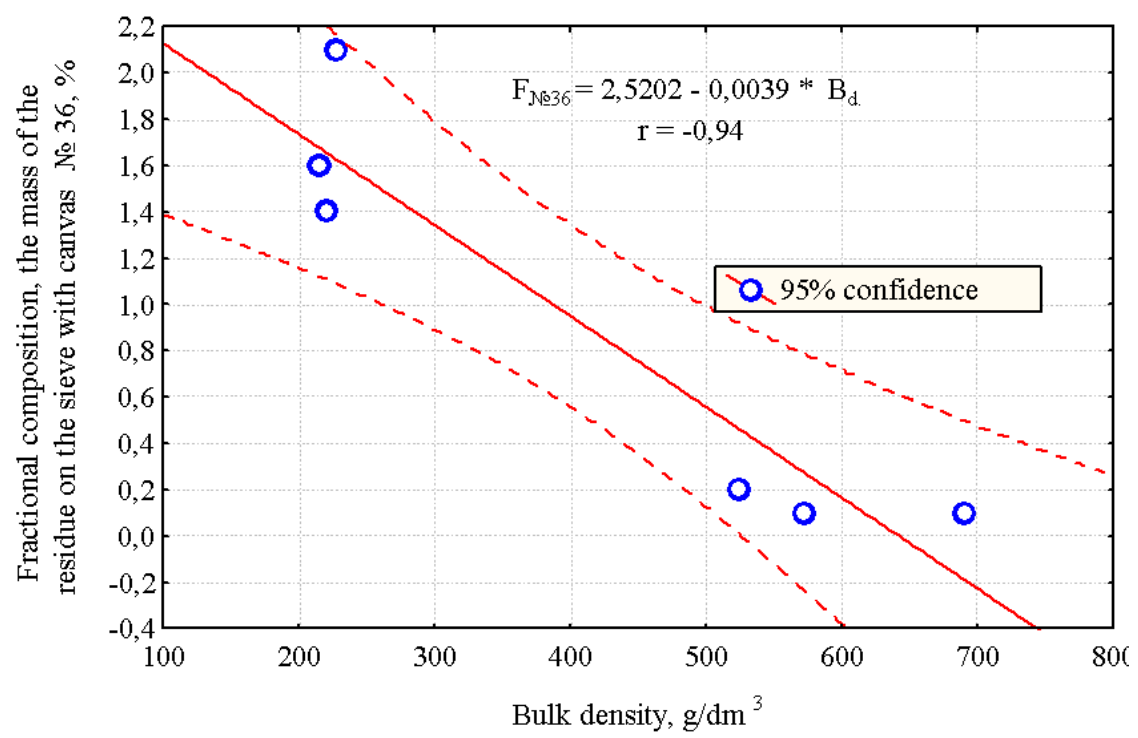

Figure 8. Dependence of bulk density for fractional composition, the mass of the residue on the sieve with canvas № 36 


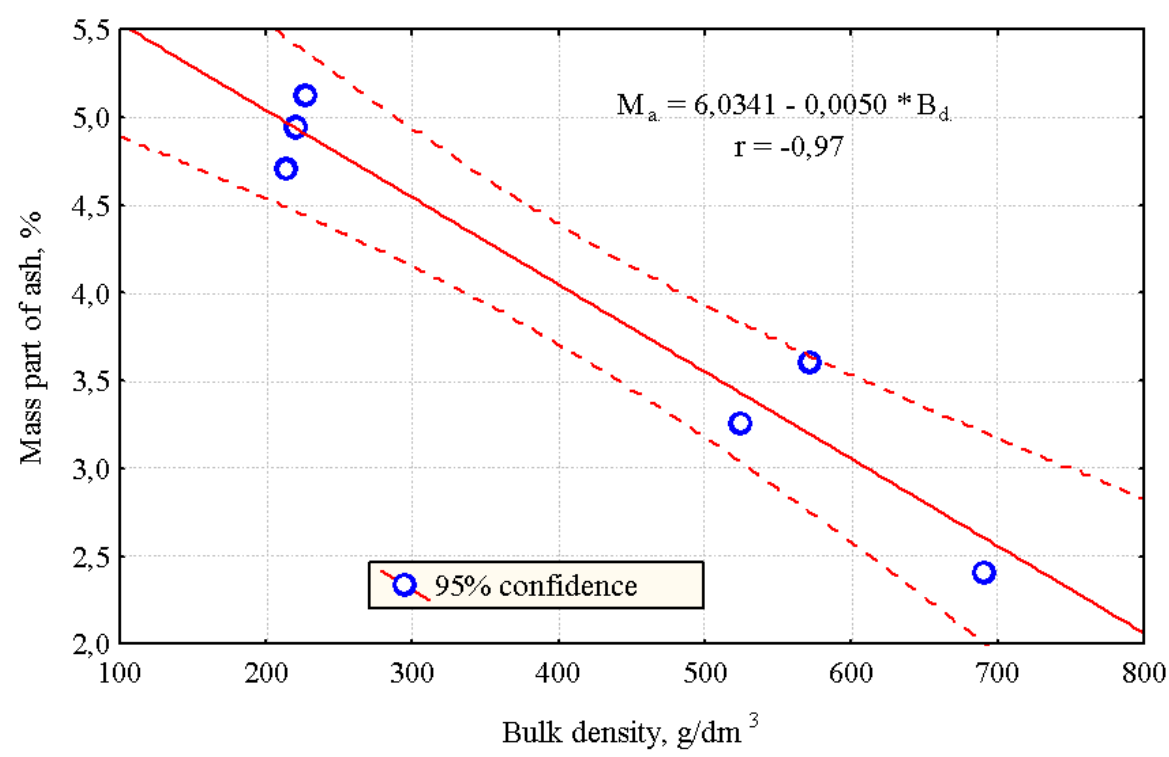

Figure 9. Dependence of bulk density for mass part of ash

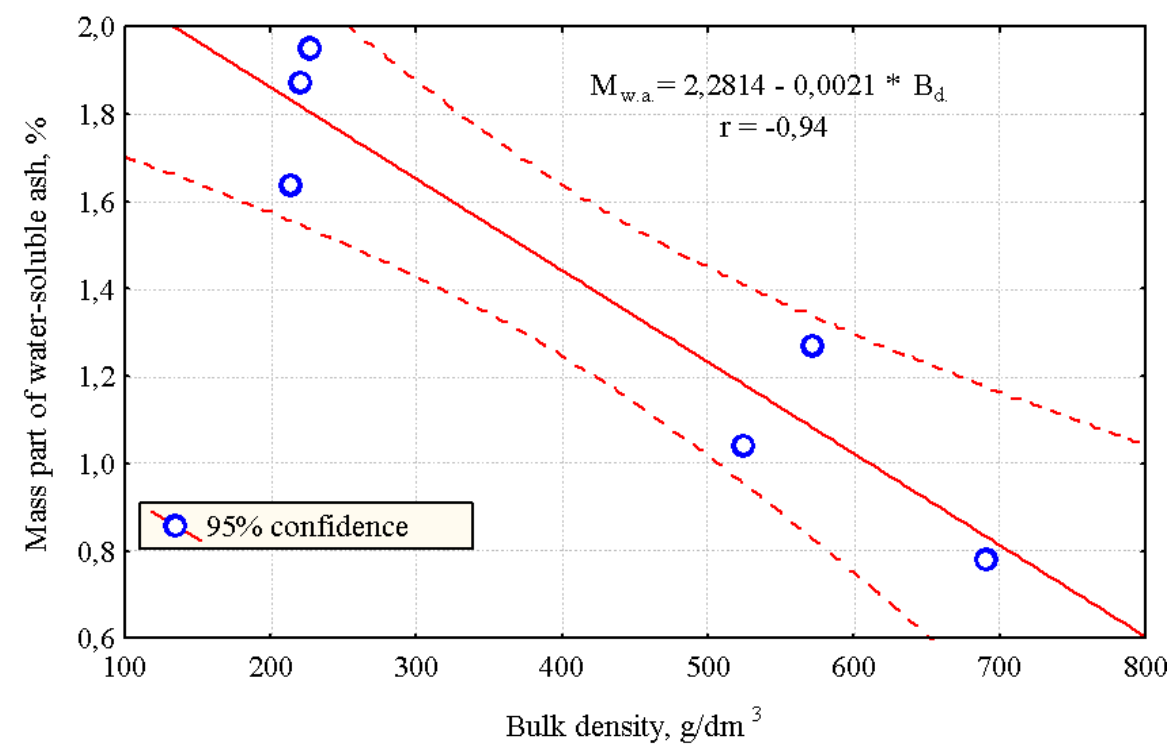

Figure 10. Dependence of bulk density for mass part of water-soluble ash

The coefficient of pair correlation $(r)$ between the indicators bulk density $\left(B_{d .}\right)$ And the mass part of the residue on the sieve with the web № $36\left(F_{\text {№36 }}\right)$ was $r=-0.94$. The coefficient of pair correlation $(r)$ between the indicators bulk density $\left(B_{d .}\right)$, The mass part of ash $\left(M_{a .}\right)$ and the mass part of water-soluble ash $\left(M_{\text {w.a. }}\right)$ was respectively $r=-0.97, r=-0.94$. All four indicators are associated with the mass of individual fractions of activated carbon. The 


\section{Food Technology}

greatest influence on the bulk density is exerted by large fractions with a mass of the residue on a sieve with web № $36\left(F_{\text {№36 }}\right)$.

For the studied active carbons, the fractional composition is typical, which is characterized by a mass portion of the residue on a sieve with cloth № $36\left(F_{\text {№36 }}\right)$ in the range of $0.1-2.1 \%$. It is she (Figure 11-12) that is directly dependent on the mass of ash $\left(M_{a .}\right)$ and the mass of water-soluble ash $\left(\mathrm{M}_{\text {w.a. }}\right)$. The coefficient of pair correlation $(r)$ between the indicators of the mass fraction of the residue on the sieve with the canvas № $36\left(F_{\text {№36 }}\right)$ and the mass fraction of the ash $\left(M_{a}\right.$.) was $r=0.91$. The coefficient of pair correlation $(r)$ between the indicators mass fraction of the residue on the sieve with the canvas № $36\left(F_{\text {№36 }}\right)$ and the mass part of water-soluble ash $\left(M_{\text {w.a. }}\right)$ was $r=0.91$. Consequently, in the largest (largest) fractions of active carbon with a mass part of the residue on a sieve with the canvas № 36 $\left(F_{\text {№36 }}=2.1 \%\right)$ in the macroporous space there is more total ash $\left(M_{a}=5.12 \%\right)$ and water-soluble $\operatorname{ash}\left(M_{w . a}=1.95 \%\right)$.

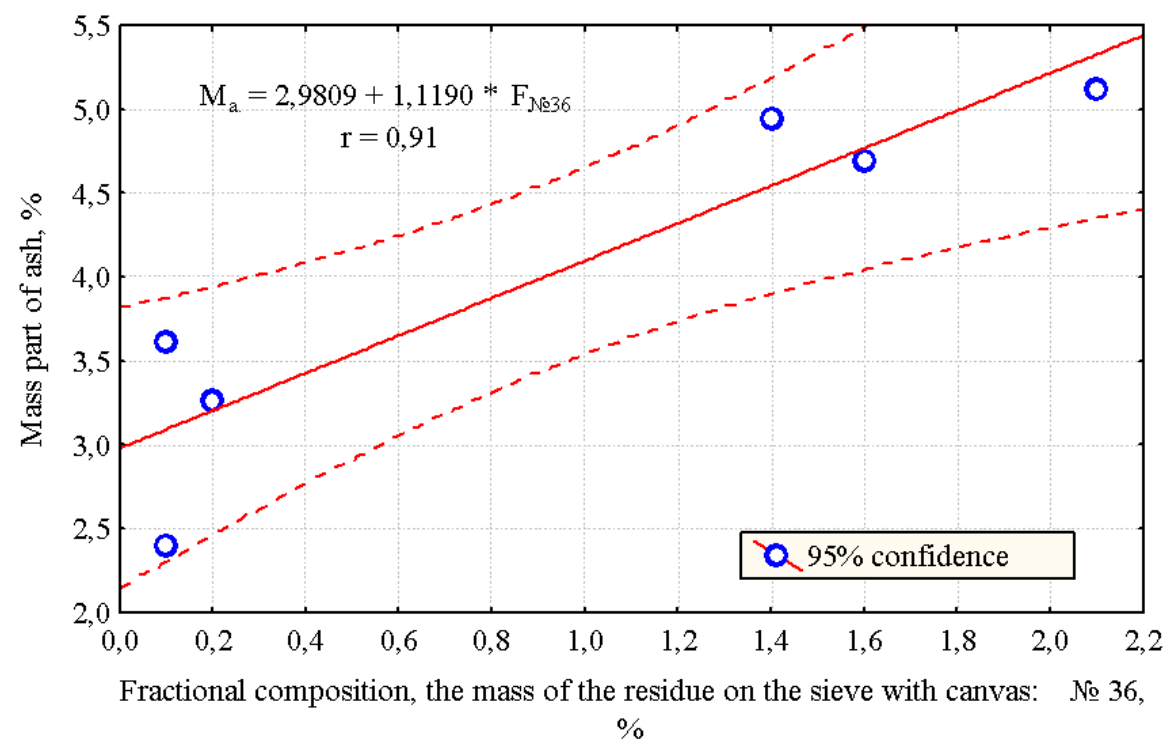

\section{Figure 11. Dependence of fractional composition, the mass of the residue on the sieve with canvas № 36 for mass part of ash}

We analyzed the relationship of the fractional composition of activated carbon, taking into account the mass fraction of the residue on the sieve with the canvas № $10\left(F_{\text {№10 }}\right)$, the value of which is in the range of $90.4-98.0 \%$, with the mass portion of the residue on the pallet $\left(F_{p}\right)$ (Figure 13). The coefficient of pair correlation $(r)$ between the indicators of the mass fraction of the residue on the sieve with the canvas № $10\left(F_{\text {№10 }}\right)$ and the mass part of the residue on the pallet $\left(F_{p}\right.$. $)$ was $r=-0.97$. Obviously, with an increase in the mass part of the residue on the sieve with the web № $10\left(F_{\text {№10 }}=98 \%\right)$, the mass part of the residue on the pallet decreases $\left(F_{p .}=0.4 \%\right)$.

The bulk of the ash $\left(M_{a .}\right)$ of the objects studied is in the range of 2.40-5.12\%. Its value (Figure 14) is directly related to the mass of water-soluble ash $\left(M_{w . a .}\right)$. The coefficient of pair correlation $(r)$ between the indicators of the mass fraction of ash and the mass fraction of 
water-soluble ash was $r=0.99$. This is characterized by a "very high" correlation force, since the value is in the range of $0.90-1.00$. Consequently, the higher the total ash content of the sorbent, the more water-soluble ash is in the composition of the activated carbon.

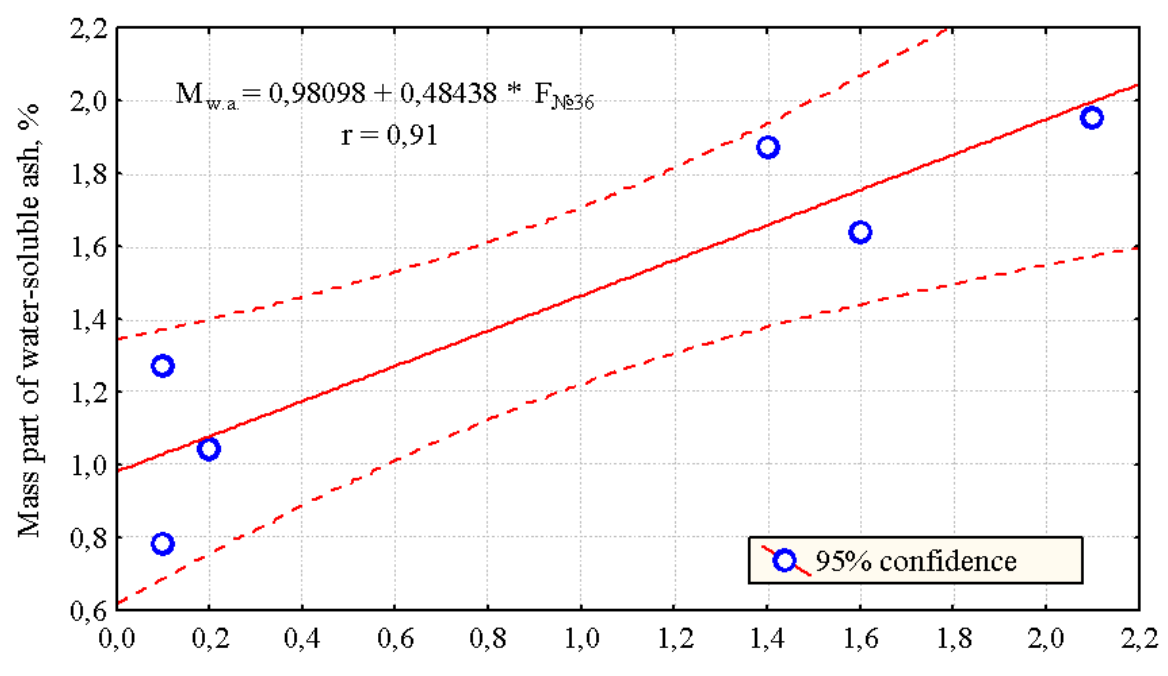

Fractional composition, the mass of the residue on the sieve with canvas: № 36 , $\%$

Figure 12. Dependence of fractional composition, the mass of the residue on the sieve with canvas № 36 for mass part of water-soluble ash

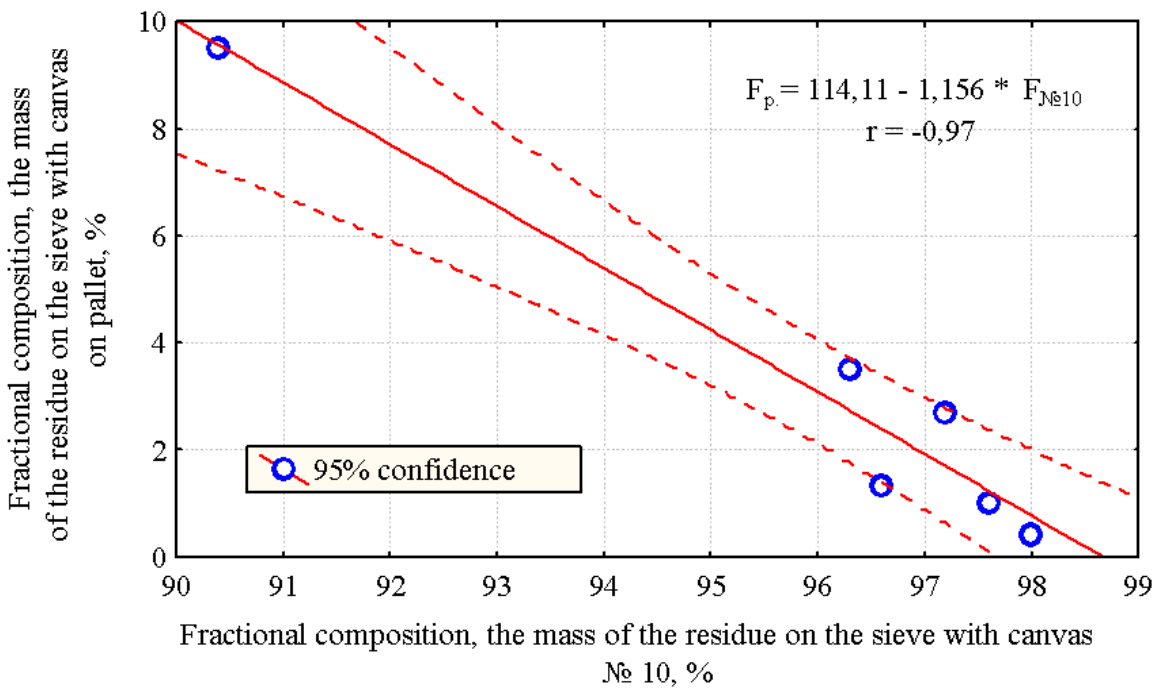

Figure 13. Dependence of fractional composition, the mass of the residue on the sieve with canvas № 10 for fractional composition, the mass of the residue on the sieve with canvas on pallet 


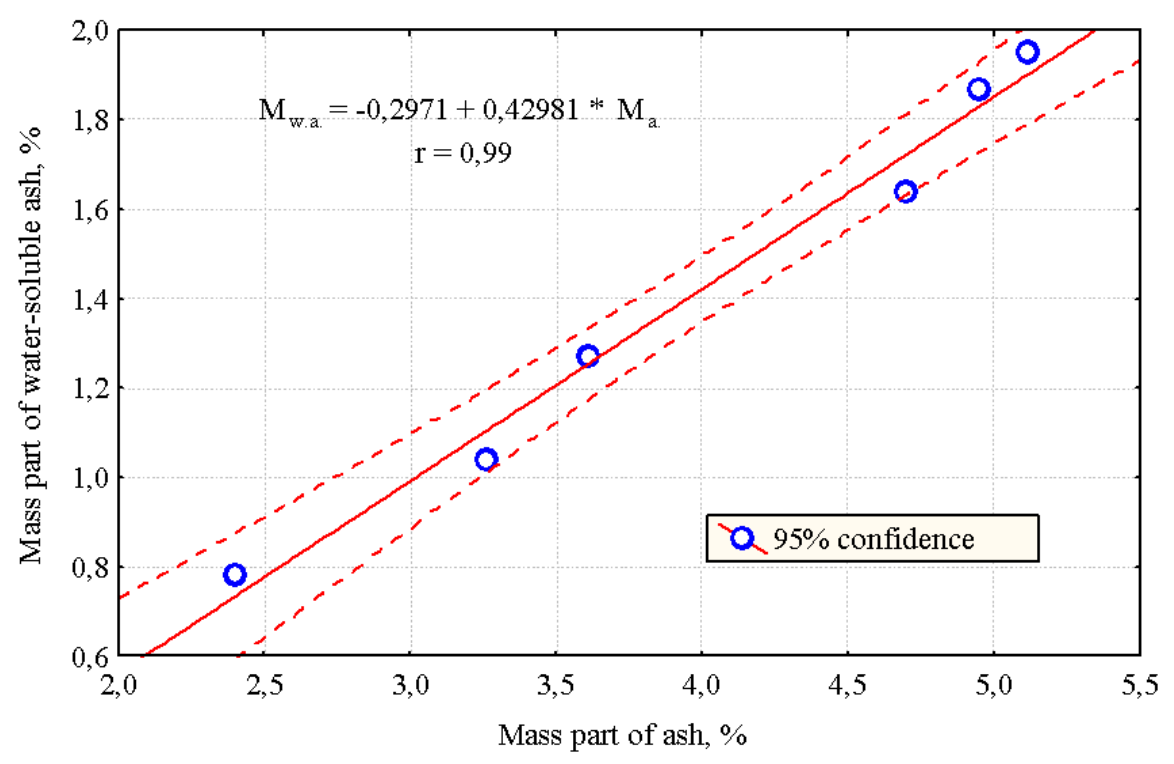

Figure 14. Dependence of mass part of ash for mass part of water-soluble ash

\section{Conclusions}

As a result of mathematical and statistical studies of a number of active carbons that are promising for use in alcoholic beverage production, the strength of the linear relationship between the variables was estimated by analyzing standard indicators of active carbons and determining the Pearson correlation coefficients. The interdependencies of such active carbon parameters are shown: iodine adsorption activity and methylene blue adsorption activity; acetic acid adsorption activity and iron content; total pore volume of water and the content of water-soluble ash, bulk density and characteristics of the fractional composition, and others.

It was found that 12 indicators out of $13(92 \%)$ have a strong internal relationship, which is characterized by "very high" correlation strength, because $r$ values are in the range of 0.90 1.00. Only one of the indicators of sorbents $\left(A_{r}-\right.$ abrasion resistance) does not have a "very high" correlation force, the highest value of the correlation coefficient $(r=-0,89)$ was obtained for a pair of characteristics - the abrasion resistance and the mass portion of the sorbent residue on the sieve canvas № $36\left(F_{\text {№36 }}\right)$.

The conducted studies are of particular interest for the selection of initial and optimization of the composition of composite sorbents from a number of available active carbons for optimizing the process of obtaining high-quality alcoholic beverages.

\section{References}

1. Oliinyk S., Kuts A., Tarasyuk L. (2016), Innovative technology of alcohol drinks. Food Science for Well-being (CEFood 2016): 8th Central European Congress on Food 2016, 
23-26 may 2016, Kyiv, 171.

2. Oliinyk S., Prybylskyi V., Chuprina N., Dovgun I. (2014), Technological advancement of sorption water purification for alcoholic beverage industry, Ukrainian Food Journal, 3(4), 559-565.

3. Kuzmin O., Topol'nik V. (2014), Eduction of unsteady equilibrium in vodkas by means of ${ }^{1} \mathrm{H}$ NMR spectroscopy, The advanced science journal, 10, pp. 43-46.

4. Kuzmin O., Topol'nik V. (2014), Eduction of transitional equilibrium in vodkas by means of ${ }^{1} \mathrm{H}$ NMR spectroscopy, The advanced science journal, 12, pp. 61-64.

5. Kuzmin O., Topol'nik V., Myronchuk V. (2014), Eduction of equilibrium state in vodkas by means of ${ }^{1} \mathrm{H}$ NMR spectroscopy, Ukrainian journal of food science, 2 (2), pp. 220-228.

6. Kuzmin O. (2015), Determination of systems with a steady equilibrium in vodkas, depending on transformation of hydroxyl protons, Ukrainian Journal of Food Science, 3(1), pp. 33-41.

7. Kuzmin O., Suikov S., Koretska I., Matiyashchuk O., Poliovyk V. (2017), Identification of equilibrium state of hydroxyl protons in vodkas by ${ }^{1} \mathrm{H}$ NMR spectroscopy, Ukrainian Food Journal, 6 (2), pp. 314-336.

8. Kuzmin O., Suikov S., Niemirich O., Ditrich I., Sylka I. (2017), Effects of the water desalting by reverse osmosis on the process of formation of water-alcohol mixtures. ${ }^{1} \mathrm{H}$ NMR spectroscopy studies, Ukrainian Food Journal, 6 (2), pp. 239-257.

9. Kuzmin O., Topol'nik V., Sujkov S. (2013), ${ }^{1}$ H NMR analysis of the aqueous-alcoholic mixtures, prepared with drinking water of south-eastern region of Ukraine, The advanced science journal, 8, pp. 21-31.

10. Kuzmin O., Topol'nik V., Fatiukha A., Volkova G. (2014), ${ }^{1}$ H NMR analysis of the aqueous-alcoholic mixtures, prepared in demineralized by reverse osmosis water, The advanced science journal, 8, pp. 235-240.

11. Kuzmin O., Topol'nik V., Fatiukha A., Volkova G. (2014), ${ }^{1} \mathrm{H}$ NMR analysis of the aqueous-alcoholic mixtures, prepared with softened water using Na-cationization, The advanced science journal, 7, pp. 9-14.

12. Kuzmin O. (2017), Mechanism of transformation of protons in the process of creating aqueous-alcoholic mixtures, Ukrainian Food Journal, 6 (4), pp. 686-697.

13. Kuzmin O.V., Marynin A.I. (2018), Concerning the prospect of using electrochemical activation in the production of alcoholic products, Engineering sciences: development prospects in countries of Europe at the beginning of the third millennium: collective monograph, Economics College in Stalowa Wola, Riga, Izdevnieciba «Baltija Publishing», 1, pp. 260-280.

14. Kuzmin O., Zubkova V., Shendrik T., Korenets Y., Kuzmin A., Bilenkyi P. (2018), Internal mechanisms for establishment of the equilibrium state of water-alcohol mixtures in vodka technology, Ukrainian Food Journal, 7(4), pp. 655-670.

15. Mukhin V.M., Polyakov V.A., Burachevskiy I.I. i dr. (2004), Vysokoprochnyye aktivnyye ugli i blochnyye fil'try na ikh osnove, Likerovodochnoye proizvodstvo $i$ vinodeliye, 55, pp. 8-9.

16. Mukhin V.M., Polyakov V.A., Makeyeva A.N., Shubina N.A. (2003), Novyye aktivnyye ugli dlya likorovodochnogo proizvodstva, Proizvodstvo spirta $i$ likorovodochnykh izdeliy, 3, pp. 36-37.

17. Petrov A.N., Olontsev V.F., Limonov N.V. (2004), Tendentsii v ispol'zovanii aktivnykh ugley v likero-vodochnoy otrasli, Likerovodochnoye proizvodstvo i vinodeliye, 57, pp. 5-7.

18. Petrov A.N., Limonov N.V. (2005), Tendentsii v ispol'zovanii aktivnykh ugley v likero- 
vodochnoy otrasli, Likerovodochnoye proizvodstvo i vinodeliye, 67, pp. 8-9.

19. Marsh H., Rodriguez-Reinoso F. (2006), Activated carbon, Elsevier, Amsterdam.

20. Rivera-Utrilla J., Sánchez-Polo M., Gómez-Serrano V., Álvarez P.M., Alvim-Ferraz M.C.M., Dias J.M. (2011), Activated carbon modifications to enhance its water treatment applications. An overview, J. Hazardous Materials, 187(1-3), pp. 1-23.

21. Bansal R.C., Goyal M. (2005), Activated carbon adsorption, Boca Raton: Taylor\&Francis Group.

22. Jiaojiao Kong, Qinyan Yue, Lihui Huang, Yuan Gao, Yuanyuan Sun, Baoyu Gao, Qian Li, Yan Wang (2013), Preparation, characterization and evaluation of adsorptive properties of leather waste based activated carbon via physical and chemical activation, Chemical Engineering Journal, 221, pp. 62-71.

23. Juan Matos, Carol Nahas, Laura Rojas, Maibelin Rosales (2011), Synthesis and characterization of activated carbon from sawdust of Algarroba wood. 1. Physical activation and pyrolysis, Journal of Hazardous Materials, 196, pp. 360-369.

24. Kuzmin O., Shendrik T., Zubkova V. (2017), Substantiation of the conditions of obtaining porous carbon materials from pyrolyzed wood wastes by chemical activation of $\mathrm{H}_{3} \mathrm{PO}_{4}$, Ukrainian Food Journal, 6(1), pp. 103-116.

25. Kuzmin O., Tamarkina J., Shendrik T., Zubkova V., Koval O., Roman T. (2017), Production of active coal from pyrolyzed wood wastes by alkaline activation of $\mathrm{KOH}$, Ukrainian Food Journal, 6(3), pp. 443-458.

26. Kwiatkowski M., Kalderis D., Diamadopoulos E. (2017), Numerical analysis of the influence of the impregnation ratio on the microporous structure formation of activated carbons, prepared by chemical activation of waste biomass with phosphoric(V) acid, Journal of Physics and Chemistry of Solids, 105, pp. 81-85.

27. Kumar A., Jena H.M. (2017), Adsorption of Cr(VI) from aqueous phase by high surface area activated carbon prepared by chemical activation with $\mathrm{ZnCl}_{2}$, Process Safety and Environmental Protection, 109, pp. 63-71.

28. Zubkova V. (2011), Study on relation of solvent extractable material and resistivity of pyrolysed coal, Journal of Analytical and Applied Pyrolysis, 92, pp. 50-58.

29. Lillo-Ródenas M.A., Marco-Lozar J.P., Cazorla-Amorós D., Linares-Solano A. (2007), Activated carbons prepared by pyrolysis of mixtures of carbon precursor/alkaline hydroxide, J. Anal. Appl. Pyrolysis, 80 (1), pp. 166-174.

30. Kinle KH., Bader E. (1984), Aktivnyye ugli i ikh promyshlennoye primeneniye, Leningrad, Khimiya.

31. Roshchina T.M. (1998), Adsorbtsionnyye yavleniya i poverkhnost', Sorosovskiy obrazovatel'nyy zhurnal, 2, pp. 89-94.

32. Lovyahin O.M., Muratov D.V., Shevchenko L.O., Koval'chuk V.P. (2008), Vplyv krotonovoho al'dehidu na yakist' spyrtu ta likero-horilchanoyi produktsiyi, Naukovi pratsi NUKHT, 24, pp. 36-38.

33. Tarasov A.V., Zav'yalov YU.F., Meskhi R.G. (2003), «Serebryanaya fil'tratsiya»novoye napravleniye $\mathrm{v}$ tekhnologii proizvodstva vysokokachestvennykh vodok, Likerovodochnoye proizvodstvo i vinodeliye, 39, pp. 1-3.

34. Zhabkina T.N., Krechetnikova A.N., Revina A.A. (2005) Primeneniye nanochastits serebra dlya modifitsirovaniya fil'truyushchikh materialov, Proizvodstvo spirta $i$ likerovodochnykh izdeliy, 1, pp. 20-21.

35. Hinkle D.E., Wiersma W., Jurs S.G. (2003), Applied statistics for the behavioral sciences, Mass: Houghton Mifflin, Boston 